\title{
ELECTROCHEMICAL AND THEORETICAL EVALUATION OF THE INTERACTION BETWEEN DNA AND AMODIAQUINE. EVIDENCE OF THE GUANINE ADDUCT FORMATION
}

\author{
Maria Lara P. M. Arguelho* e José do Patrocínio H. Alves \\ Departamento de Química, Universidade Federal de Sergipe, 49100-000 São Cristovão - SE, Brasil \\ Nelson R. Stradiotto \\ Instituto de Química, Universidade Estadual Paulista, CP 355,14801-970 Araraquara - SP, Brasil \\ Valdemar Lacerda Júnior e José Maria Pires \\ Departamento de Química, Universidade Federal do Espírito Santo, 29075-910 Vitória - ES, Brasil \\ Adilson Beatriz \\ Departamento de Química, Universidade Federal de Mato Grosso do Sul, 79070-900 Campo Grande - MS, Brasil
}

Recebido em 4/9/09; aceito em 3/2/10; publicado na web em 18/6/10

\begin{abstract}
The electrochemical behavior of the interaction of-amodiaquine with DNA on a carbon paste electrode was studied using voltametric techniques. In an acid medium, an electroactive adduct is formed when amodiaquine interacts with DNA. The anodic peak is dependent on $\mathrm{pH}$, scan rate and the concentration of the pharmaceutical. Adduct formation is irreversible in nature, and preferentially occurs by interaction of the amodiaquine with the guanine group. Theoretical calculations for optimization of geometry, and DFT analyses and on the electrostatic potential map (EPM), were used in-the investigation of adduct formation between amodiaquine and DNA.
\end{abstract}

Keywords: amodiaquine; guanine; adduct.

\section{INTRODUCTION}

In most cases, electrochemical investigation of the interaction between pharmaceuticals and DNA involves the induction of changes in the redox properties of the pharmaceuticals, since these organic ${ }^{1,2}$ or inorganic ${ }^{3-6}$ substances often contain electrochemically active functional groups in their chemical structures.

However, in biomedical, environmental and other areas of research, information concerning pharmaceutical/DNA systems can be obtained by employing versatile biosensors based on DNA. Recent research has developed different types of biosensors, where the main objective has been to explore the interaction between DNA, confined to the surface of an electrode, and the pharmaceutical in question. The results of such research can serve as a model to evaluate the correlation between the biological action and damage to the DNA, ${ }^{7-11}$ in relation to the mode of action of the pharmaceutical in biological systems.

An example is given by the work of Girousi and co-workers, ${ }^{12}$ showing the interaction of rifampicin, a broad-spectrum antibiotic, with DNA immobilized on a

carbon paste electrode. Piedade and co-workers ${ }^{13}$ investigated the interaction of adriamycin with calf thymus DNA physically immobilized on the surface of a glassy carbon electrode. According to these authors, adriamycin causes rupture of the helical DNA structure, with oxidation of DNA indicated by detection of the oxidation marker 8-oxoguanine, formed during the in vivo metabolism of the pharmaceutical.

Various studies have suggested that some of the aminoquinolinic pharmaceuticals used in the treatment of malaria can bind with nucleoproteins, hence inhibiting DNA replication and RNA synthesis. ${ }^{14,15}$ On the other hand, recent research indicates that mutation of the transmembrane protein present in the digestive vacuole of Plasmodium falciparum is the key to understanding the organism's

*e-mail: marguelho@bol.com.br mechanism of resistance to chloroquine, one of the main aminoquinolinic compounds employed in the treatment of malaria. ${ }^{16,17}$ In fact, affinity between chloroquine and DNA has been used by $\operatorname{Radi}^{18}$ to quantify this antimalarial agent in biological fluids. The biosensor was obtained by immobilization of DNA on a carbon paste electrode. Nonetheless, few electrochemical methods have been developed to study the interaction of other aminoquinolinic derivatives with DNA.

Amodiaquine is a 4-aminoquinolinic derivative (Figure 1) considered to be a powerful chemotherapeutic for the treatment of malaria caused by Plasmodium falciparum, used either alone or in combination with sulfadoxine-pyrimethamine, and is a safe and effective option for the treatment of malaria caused by strains that are either sensitive or resistant to chloroquine. ${ }^{19,20}$

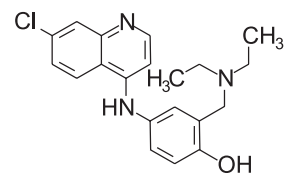

Figure 1. Amodiaquine chemical structure

Within this context, the present study aims to investigate the mechanism of interaction of amodiaquine with DNA using electrochemistry, since covalent attack of DNA on the carbon paste electrode surface provides a controlled environment in which the kinetic and thermodynamic parameters of the DNA-pharmaceutical interaction can be better evaluated.

\section{EXPERIMENTAL}

\section{Reagents}

The reagents amodiaquine diphosphate (AMD), sodium salt calf thymus DNA (type II), guanine and adenine were obtained from 
Sigma. Britton-Robinson ${ }^{21}$ (B-R) buffer was prepared by mixing $0.01 \mathrm{~mol} \mathrm{~L}^{-1}$ phosphoric acid, $0.01 \mathrm{~mol} \mathrm{~L}^{-1}$ boric acid and $0.01 \mathrm{~mol}$ $\mathrm{L}^{-1}$ acetic acid with an appropriate volume of $0.2 \mathrm{~mol} \mathrm{~L}^{-1} \mathrm{NaOH}$. The buffer solutions were prepared using analytical grade reagents and deionised water supplied from a Millipore Milli-Q system.

The solutions containing DNA used for electrode modification were prepared by the dissolution of $3 \mathrm{mg}$ of Calf thymus DNA in $0.5 \mathrm{~mL}$ of concentrated perchloric acid, with $0.5 \mathrm{~mL}$ of $9.0 \mathrm{~mol} \mathrm{~L}^{-1}$ $\mathrm{NaOH}$ added after dissolution to neutralise the medium, according to the procedure employed by Brett and co-workers to prepare solutions containing single stranded DNA. ${ }^{22}$

The carbon paste electrode was prepared using 1-2 $\mu$ m diameter powdered graphite (Aldrich, Milwaukee) and $0.84 \mathrm{~g} \mathrm{~mL}^{-1}$ density mineral oil (Sigma).

\section{Instrumentation}

Voltametric analyses were performed using an Autolab potentiostat, controlled by GPES v.4.8 software (EcoChemie, Utrecht, Netherlands). A single compartment, $5.0 \mathrm{~mL}$ capacity, electrochemical cell was fitted with a carbon paste working electrode, a platinum auxiliary electrode, and an $\mathrm{Ag} / \mathrm{AgCl}$ reference electrode.

\section{Procedure}

\section{Electrochemistry}

There are three stages involved in the development of an electrode modified for analysis of DNA/pharmaceutical interactions: immobilization of the DNA-pharmaceutical species, conditioning of the electrode following modification, and analysis of the voltametric response of the system.

A carbon paste electrode can contain different proportions of powdered graphite and mineral oil. Here, the graphite used was initially heated at $100{ }^{\circ} \mathrm{C}$ for $12 \mathrm{~h}$, the graphite/oil mixture prepared at a ratio of $3: 1$, and the paste obtained homogenized and packed into a $0.5 \mathrm{~cm}$ internal diameter plastic tube to give a paste thickness of $0.3 \mathrm{~cm}$. A platinum thread was used as an electrical contact. This electrode was used to investigate the electrochemical behavior of amodiaquine at a concentration of $1.0 \times 10^{-3} \mathrm{~mol} \mathrm{~L}^{-1}$ in B-R buffer solution ( $\mathrm{pH} 4.0$ ).

The electrode modified with DNA was obtained using a freshly prepared carbon paste electrode, which was coated with $3.0 \mu \mathrm{L}$ of a solution containing DNA and then allowed to dry in an anhydrous environment for $4 \mathrm{~h}$. After drying, the electrode was immersed in buffer solution (B-R, pH 4.0) for $30 \mathrm{~min}$.

\section{Theory}

All the theoretical calculations were performed using the Gaussian 03 software package. ${ }^{23}$ The semi-empirical PM3 method was employed for an initial pre-optimization. Full geometrical optimization for amodiaquine (AMD), protonated amodiaquine $\left(\mathrm{AMD}-\mathrm{H}^{+}\right)$, adenine (ADE) and guanine (GUA) was achieved using the Hartree-Fock method (3-21G basis set, B3LYP hybrid functional and the 6-31G(d) collection of basis set functions). ${ }^{24}$ All of the stationary points were characterized as minima or transition structures by calculation of the vibrational harmonic frequencies. DFT analysis of the overall indices of electrophilicity $(\omega)$, chemical electronic potential $(\mu)$ and hardness $(\eta)$ were based on the energy of the frontier HOMO-LUMO molecular orbitals obtained at the B3LYP/6-31+G(d,p) level. Electrostatic potential maps (EPMs) were obtained for structures optimized using the Gauss View 3.0 program. $^{25}$

\section{RESULTS AND DISCUSSION}

\section{Electrochemical behavior}

Cyclic voltammetry showed that amodiaquine in contact with a carbon paste electrode presented well-defined anodic and cathodic peaks. Increase of the scan rate $(v)$ shifted the anodic potential $\left(E_{a p}\right)$ to more negative values (Figure 2), with a difference between anodic and cathodic peaks $\left(\Delta \mathrm{E}_{\mathrm{p}}\right)$ of $0.305 \mathrm{~V}\left(\mathrm{v}=0.05 \mathrm{~V} \mathrm{~s}^{-1}\right)$. According to established literature mechanistic criteria, ${ }^{26}$ this value is greater than would be expected for a reversible monoelectronic transfer without participation of chemical reactions.

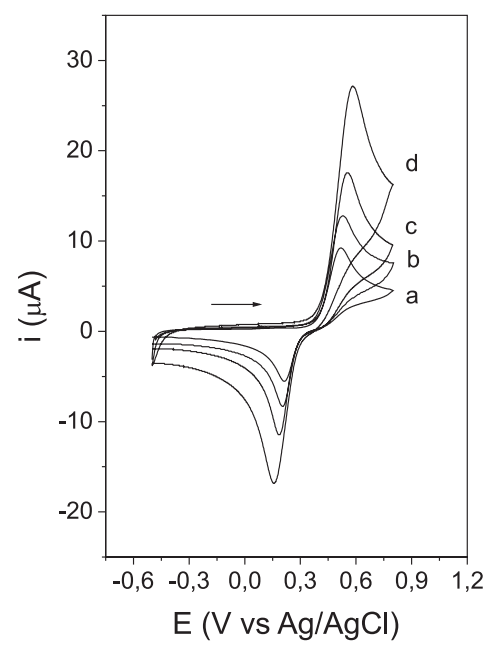

Figure 2. Cyclic voltammograms of amodiaquine $1.0 \times 10^{-3} \mathrm{~mol} \mathrm{~L}^{-1}$ in BR buffer $(\mathrm{pH} 4.0)$. a) $\mathrm{v}=0.05, \mathrm{~b}) \mathrm{v}=0.2$ and c) $\mathrm{v}=0.5 \mathrm{~V} \mathrm{~s}^{-1}$

Investigation of the influence of solution $\mathrm{pH}$ on amodiaquine oxidation showed that both oxidation current and potential were $\mathrm{pH}$ dependent (Figure 3). The anodic current rises with increasing of $\mathrm{pH}$ until 6.0, when an abrupt decrease of the solubility of amodiaquine in solution occurs. The shift of the oxidation potential to less negative values, of around $49 \mathrm{mV} \mathrm{pH}^{-1}$. Such a shift is indicative of the participation of protons in the electron transfer rate-determining step. ${ }^{26}$

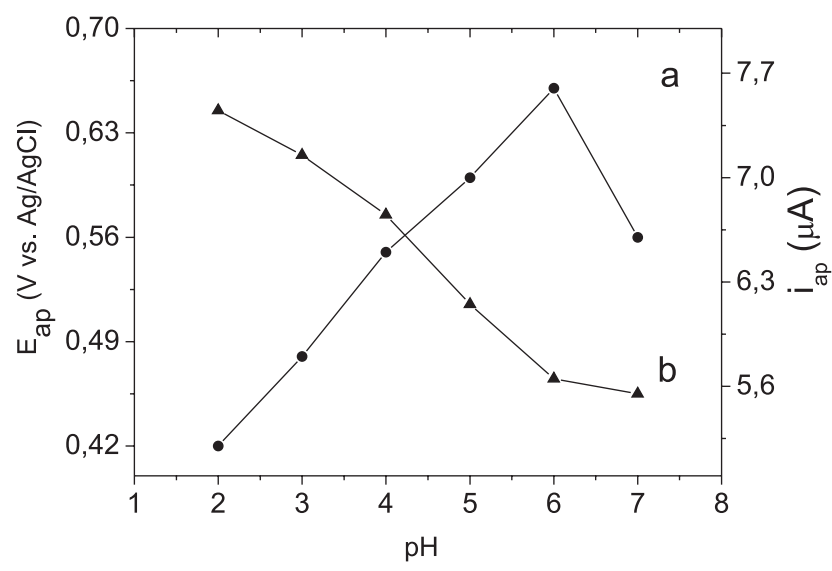

Figure 3. Dependence of the $i_{a p}$-anodic peak current (a) and $E_{a p}$-anodic peak potential (b) to amodiaquine $1.0 \times 10^{-3}$ mol $L^{-1}$ solution on the $p H$. Conditions: $\mathrm{v}=0.1 \mathrm{~V} \mathrm{~s}^{-1}, \mathrm{~B}-\mathrm{R}$ buffer

Increasing the amodiaquine concentration caused a proportional increase in the peak current $\left(\mathrm{i}_{\text {ap }}\right)$. Diffusional control of the current was evidenced by the proportionality between the anodic current $\left(\mathrm{i}_{\text {ap }}\right)$ 
and the square root of the scan speed $\left(v^{1 / 2}\right)$, and by the constant value of the current function $\left(\mathrm{i}_{\mathrm{ap}} / \mathrm{v}^{1 / 2}\right)$ in the 0.01 to $1.0 \mathrm{~V} \mathrm{~s}^{-1}$ interval. This current behavior was accompanied by an anodic potential $\left(\mathrm{E}_{\mathrm{ap}}\right)$ shift of $+55 \mathrm{mV}$ with increasing potential scan speed, as is often observed in electrodic processes where electron transfer $(\mathrm{E})$ is followed by a chemical reaction (C), usually termed a type EC mechanism.

The number of electrons was obtained from chronoamperometric measurements on a timescale of $0.5<\mathrm{t}<5 \mathrm{~s}$, at $\mathrm{pH}$ values of 2-7 in solutions containing $1.0 \times 10^{-3} \mathrm{~mol} \mathrm{~L}^{-1}$ of amodiaquine. Under these conditions, the term i.t $\mathrm{t}^{-1 / 2} / \mathrm{C}$ showed constant values, corresponding to the transfer of one electron per molecule of amodiaquine. These results suggest that the electrochemical behavior of amodiaquine, in a protic medium, is similar to that of other compounds possessing a phenolic group in their structures. ${ }^{27}$ In general terms, monoelectronic oxidation of a diprotonated form results in formation of a cation radical that, as with other cation radicals formed by oxidation of a phenolic group, can be consumed in coupling reactions of the type $\mathrm{C}-\mathrm{C}$ or $\mathrm{C}-\mathrm{O}$, forming dimeric species. ${ }^{28}$

Considering that, in a biological medium, biomolecules can act as the surface of an electrode, promoting a heterogeneous charge transfer, understanding of the electrochemical properties of amodiaquine, such as the formation of radical species after its oxidation, and the interaction of the pharmaceutical itself with biomolecules, could contribute to a better understanding of its mechanism of action and toxicity. DNA is indisputably one of the biomolecules most cited in the literature, due to its reactivity and participation in the mode of action and toxicity of many pharmaceuticals. Here, the cyclic voltammogram of amodiaquine on an electrode modified with DNA showed well defined anodic and cathodic peaks (Figure 4), evidence that the amodiaquine was securely bound to the electrode surface. On a carbon paste electrode, the oxidation potential of amodiaquine is $0.52 \mathrm{~V}$ (vs. $\mathrm{Ag} / \mathrm{AgCl}$ ), while that of an electrode modified with DNA is $0.60 \mathrm{~V}$ (vs. $\mathrm{Ag} / \mathrm{AgCl}$ ). According to the literature, ${ }^{29,30}$ species that are electrochemically oxidized at potentials below $1.0 \mathrm{~V}$ can also be oxidized in biological media.

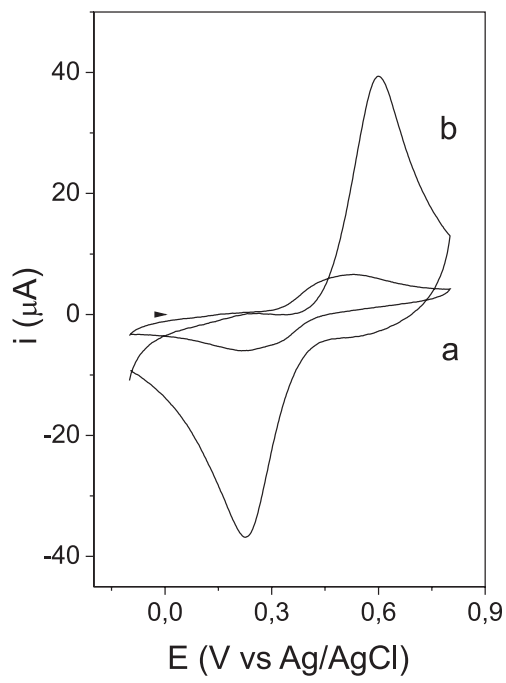

Figure 4. Cyclic voltammograms of amodiaquine $1.0 \times 10^{-3}$ mol. $L^{-1}$ in $B R$ buffer (pH 4.0). a) carbon paste electrode and b) DNA electrode. $v=0.5 \mathrm{~V} \mathrm{~s}^{-1}$

Using differential pulse voltammetry, it was observed that the peak anodic current increased in the presence of DNA, and that the formal potential $\left(\Delta \mathrm{E}^{\circ}\right.$ ') shifted by $+80 \mathrm{mV}$. According to Equation 1 below, the ratio $\left(\mathrm{K}_{\text {oxid }} / \mathrm{K}_{\text {red }}\right)$ between the surface binding constants for amodiaquine in the oxidized $\left(\mathrm{K}_{\text {oxid }}\right)$ and reduced $\left(\mathrm{K}_{\text {red }}\right)$ forms can be estimated to be equal to 22 .

$$
\Delta \mathrm{E}^{\mathrm{o}^{\prime}}=\mathrm{RT} /(\mathrm{nF}) \ln \left(\mathrm{K}_{\mathrm{oxid}} / \mathrm{K}_{\mathrm{red}}\right)
$$

This suggests that the oxidized form of amodiaquine interacts more strongly with DNA than does the reduced form (by about 22 times). The oxidized form probably presents a greater interaction with the nitrogenated bases that comprise part of the DNA structure. According to the literature, ${ }^{31,32}$ this type of behavior is characteristic of interactions that involve intermixing, and are not merely electrostatic.

As in the study of the effect of $\mathrm{pH}$ on the oxidation of amodiaquine on a carbon paste electrode, solution $\mathrm{pH}$ had a significant influence on the electroactivity of amodiaquine on an electrode modified with DNA. A wide range of oxidation potential was observed as a function of $\mathrm{pH}$, with a variation of $110 \mathrm{mV} \mathrm{pH}^{-1}$ in the $\mathrm{pH}$ range 5-9. In principle, the influence of scan speed can provide qualitative information concerning the electrochemical behavior of a system. Here, the electrodic behavior of amodiaquine was compared in the presence or absence of DNA (Table 1). Comparison of oxidation potentials indicates that the anodic shift was four times smaller in the absence of DNA. Qualitatively, in the presence of DNA, $\Delta \mathrm{E}_{\mathrm{p}}$ increased as a function of scan speed, indicating that the kinetics of electron transfer was slower, considering the cyclic voltammetry timescale.

Table 1. Electrochemical behavior of AMD and AMD-DNA modified electrode in relation to scan rate

\begin{tabular}{lcc}
\hline Parameters & AMD (electrode II) & ${ }^{a}$ AMD/DNA (electrode III) \\
\hline $\mathrm{E}_{\text {ap }}(\mathrm{V})$ vs $\log v$ & 0.03 & 0.12 \\
$\Delta \mathrm{E}_{\mathrm{p}}(\mathrm{V})$ vs $\log v$ & 0.12 & 0.23 \\
$\mathrm{i}_{\text {ap }} / v^{1 / 2}$ vs $v\left(\mathrm{~V}^{-1}\right)$ & 1.0 & 11.4 \\
$\mathrm{i}_{\mathrm{cp}} / \mathrm{i}_{\text {ap }}\left(\mathrm{v}=0.01 \mathrm{~V} \cdot \mathrm{s}^{-1}\right)$ & 0.8 & 1.0 \\
\hline
\end{tabular}

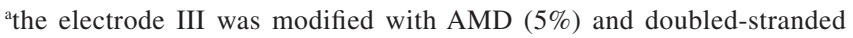
$\operatorname{DNA}(95 \%) \mathrm{w} / \mathrm{w}$.

For voltametric measurements on the carbon paste electrode, the current function $\left(\mathrm{i}_{\text {ap }} / \mathrm{V}^{1 / 2}\right)$ showed an exponential increase up to a maximum value of 1.0 for scan speeds below $0.5 \mathrm{~V} \mathrm{~s}^{-1}$. This behavior is frequently obtained in processes where chemical reaction occurs after electron transfer. Similar behavior was observed for the electrode modified with DNA. However, differences in the $\mathrm{i}_{\mathrm{cp}} / \mathrm{i}_{\text {ap }}$ ratio indicate that a possible dimerization reaction, observed in the case of the carbon paste electrode, may not occur when amodiaquine is intermixed in the structure of the DNA immobilized on the electrode surface.

According to the literature, ${ }^{33}$ DNA is also an electroactive species, and its oxidation involves a complex process of guanine and adenine oxidation. Complete oxidation of guanine occurs at $0.95 \mathrm{~V}$ (vs. Ag/ $\mathrm{AgCl}$ ), while in the case of adenine the value shifts to $1.22 \mathrm{~V}$ (vs. $\mathrm{Ag} / \mathrm{AgCl}$ ), with the loss of four electrons and participation of four protons in both electrodic processes. The principal mechanisms of the electrochemical oxidation of these purine groups are illustrated in Scheme 1S (supplementary material).

The hypothesis of adduct formation between amodiaquine and either adenine or guanine groups was investigated using solutions containing adenine or guanine.

Experiments employing the carbon paste electrode showed that the electrochemical behavior of amodiaquine remained unchanged in the presence of adenine. However, the oxidation peak of guanine showed a current increase in the presence of amodiaquine (Figure 5, peak 2a). The amodiaquine oxidation peak disappears in the presence of guanine, being replaced by peaks $3 \mathrm{a}$ and $4 \mathrm{a}$ (Figure 5). These peaks are probably due to reaction between amodiaquine and guanine.

Adduct formation between aromatic amines or phenols, and guanine, has been described in the literature as a reaction that occurs preferentially with the $\mathrm{N} 2$ or $\mathrm{N} 7$ nitrogen present in the guanine 
structure. Biological studies have revealed the formation of this type of adduct in the interaction of guanine with aniline $e^{34,35}$ and some quinolinic derivatives. ${ }^{36,37}$ Other studies indicate that electrophilic quinines react with DNA via the Michael Addition 1.4 mechanism, with the N7 nitrogen of guanine being the main nucleophilic region involved in adduct formation. In all cases, there are structural similarities with amodiaquine. ${ }^{38-40}$

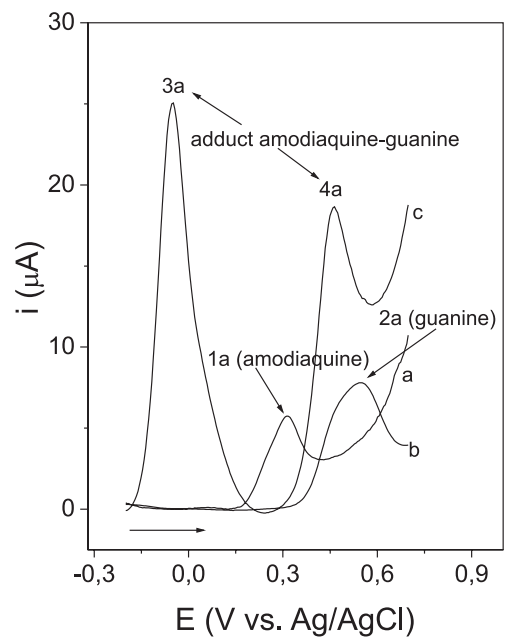

Figure 5. Pulse differential voltammograms in solution $B-R(p H 4.0)$ in carbon paste electrode. a) only amodiaquine $\left(5.0 \times 10^{-6} \mathrm{~mol} \mathrm{L^{-1 }}\right)$, b) only guanine $\left(8.0 \times 10^{-4} \mathrm{~mol} \mathrm{~L}^{-1}\right)$ and c) amodiaquine $\left(6.0 \times 10^{-5} \mathrm{~mol} \mathrm{~L}^{-1}\right)$ and guanine $(8.0$ $\left.x 10^{-4} \mathrm{~mol} \mathrm{~L}^{-1}\right)$ in the same solutions. Conditions: $\Delta E=50 \mathrm{mV}, t=5.0 \mathrm{~ms}$ and $\mathrm{v}=5.0 \mathrm{mV} \mathrm{s}^{-1}$

\section{Theoretical studies}

In combination with experimental results, theoretical calculations can be a powerful tool to support reaction mechanism hypotheses. In this work, the reactivity of amodiaquine with adenine (ADE) and guanine (GUA) was evaluated (Figure 6). In order to suggest possible structures of the adducts formed, a theoretical study involving geometry optimization was undertaken, together with DFT analysis of $\omega, \mu$ and $\eta$ indices and mapping of electrostatic potentials.<smiles>CCN(CC)Cc1cccc(Nc2ccnc3cc(Cl)ccc23)c1O</smiles>

AMD<smiles></smiles>

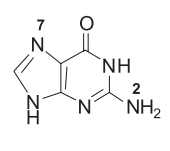

GUA
Figure 6. Structures used in the theoretical calculations

The global $\omega, \mu$ and $\eta$ indices, obtained from the energy of the HOMO-LUMO frontier molecular orbitals, were examined to support the experimental results indicating that amodiaquine reacted with guanine but not with adenine (Table 2).

The global index $\omega$, which measures the stabilization of the energy when the system acquires an additional electronic charge, $\Delta N$, from the environment, has been given by the expression ${ }^{41,42} \omega=$ $\mu^{2} / 2 \eta$, where the chemical electronic potential, $\mu$, and the chemical hardness, $\eta$, can be considered in terms of the energy of an electron from the HOMO and LUMO frontier molecular orbitals, $\mathrm{E}_{\mathrm{H}}$ and $\mathrm{E}_{\mathrm{L}}$, as $\mu \approx \mathrm{E}_{\mathrm{H}}+\mathrm{E}_{\mathrm{L}} / 2$ and $\eta \approx \mathrm{E}_{\mathrm{L}}-\mathrm{E}_{\mathrm{H}}$, respectively. ${ }^{43,44}$

The index of electrophilicity encompasses both the propensity of the electrophile to acquire an additional electronic charge, driven by the square of the electronegativity $\left(\mu^{2}\right)$, and the resistance of the system to exchange electronic charge with the environment, described by $\eta$, simultaneously. A good electrophile is characterized by a high $\mu$ value, a low $\eta$ value, and an elevated $\omega$ value.

As can be seen from Table 2, from analysis of the global indices it was possible to confirm that the protonated amodiaquine (AMD- $\left.\mathrm{H}^{+}\right)$ is the best electrophile $(\omega=8.75)$. On the other hand, guanine is the best nucleophile $(\omega=1.10)$.

Table 2. Global indexes* $(\mu, \eta$ e $\omega)$ calculated at B3LYP/6-31+G(d,p)

\begin{tabular}{lccccc}
\hline Compound & HOMO & LUMO & $\boldsymbol{\mu}$ & $\eta$ & $\omega$ \\
\hline AMD-H & -0.3208 & -0.2109 & -0.2659 & 0.1099 & 8.75 \\
AMD & -0.2083 & -0.0627 & -0.1355 & 0.1456 & 1.72 \\
ADE & -0.2310 & -0.0337 & -0.1324 & 0.1973 & 1.21 \\
GUA & -0.2241 & -0.0279 & -0.1260 & 0.1962 & 1.10 \\
\hline
\end{tabular}

* HOMO, LUMO, Electronic chemical potential, $\mu$, and chemical hardness, $\eta$, values are in au; electrophilicity power values, $\omega$, are in $\mathrm{eV}$.

With this information, it was possible to propose two different structures for the adduct formed between amodiaquine and guanine, that only differ in the position where the guanine (nucleophile) attacks the AMD- $\mathrm{H}^{+}$(electrophile), as can be seen in Figure 7. A proposed mechanism of this transformation is illustrated in Scheme 1.
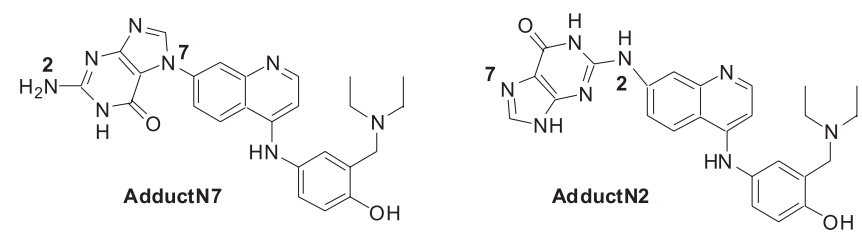

Figure 7. Possible structures of adducts amodiaquine-guanine
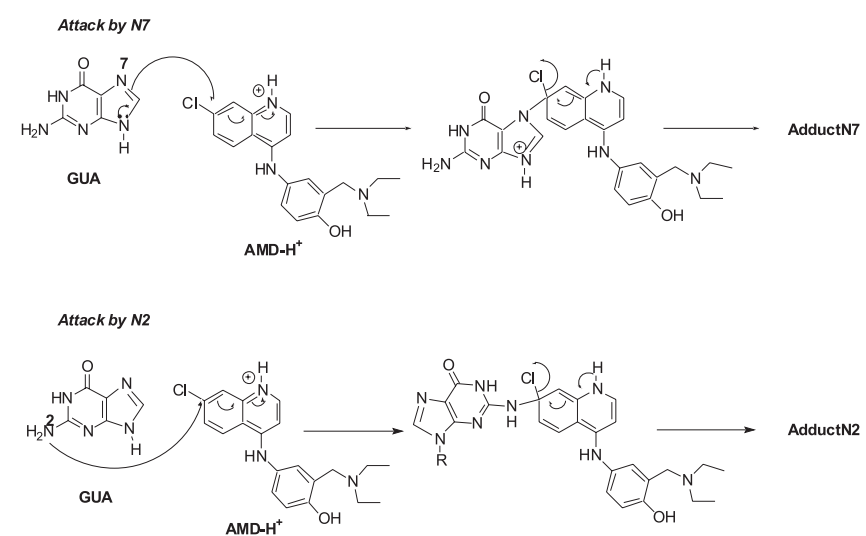

Scheme 1. Proposed mechanism for the adduct formation

In order to obtain information on the stability of the proposed adducts, and decide which position (N7 or N2) is favored for the attack on AMD- $\mathrm{H}^{+}$, the first approach was to check the difference between the energies of the two possible adducts. The results are presented in Table 3.

Table 3. Energies (atomic unit) and energy difference (kcal/mol) for proposed adducts for the reaction between amodiaquine (AMD) and guanine (GUA) calculated at the B3LYP/6-31G(d) level

\begin{tabular}{lcc}
\hline Adduct & Energy (atomic unit) & $\Delta \mathrm{E}(\mathrm{kcal} / \mathrm{mol})$ \\
\hline Adduct N7 & -1556.81189851 & 0.0 \\
Adduct N2 & -1556.81143526 & +0.29 \\
\hline
\end{tabular}


From the results of the theoretical calculations (Table 3), it can be observed that the energy for Adduct N2 is $0.29 \mathrm{kcal} \mathrm{mol}^{-1}$ higher than that for Adduct-N7. The energy difference between the two possible adducts is very small, so that it is not possible to derive any information concerning the attack.

The second approach, based on EPM, provides valuable information on the possible attack positions. The EPMs show the electronic density localized in each region of the atom or molecule, which can be useful in the present case. Figure 1S (supplementary material) illustrates the EPMs obtained for the compounds studied using the Gauss View 3.0 software, employing the respective optimized structures.

The EPM results clearly show that the protonated amodiaquine $\left(\mathrm{AMD}-\mathrm{H}^{+}\right)$is the compound with greater positive character (blue potential), confirming the global index results (AMD- $\mathrm{H}^{+}$as the best electrophile). However the EPM of guanine appears to be decisive in defining which position, N7 or N2, is favored for the attack of guanine on the protonated amodiaquine. Analyzing the EPM of guanine and comparing the regions around N7 and N2 can easily resolve this. An electronic denseness can be clearly seen around N7 (red potential), while there is an electronic deficiency around N2 (blue potential). These results suggest that the most nucleophilic site is on N7 and, therefore, the adduct formed must be the Adduct-N7.

\section{CONCLUSIONS}

Electrochemical analysis of the interaction of DNA, supported on an electrode, with a pharmaceutical in solution, is shown to be a convenient method for investigation of the dynamics of DNA mediation in electronic transfer.

The redox behavior of amodiaquine, in the presence of DNA, is especially interesting due to the possible relationship with its toxic effects when employed as an antimalarial treatment. The intermixing of amodiaquine with the DNA structure, with subsequent adduct formation between amodiaquine and guanine, may contribute to greater vulnerability of DNA to oxidative processes. This hypothesis is supported by theoretical calculations showing that amodiaquine has a greater electronic affinity for guanine, than for adenine, and that the preferential pathway for formation of the amodiaquine-guanine adduct is via the N7 nitrogen of the guanine structure.

\section{SUPPLEMENTARY MATERIAL}

Available on http://quimicanova.sbq.org.br, in PDF file, free of charges.

\section{ACKNOWLEDGMENTS}

The authors are grateful for financial support from FAPESP, $\mathrm{CNPq}$ and CAPES.

\section{REFERENCES}

1. Lu, W.; Vicic, D. A.; Barton, J. K.; Inorg. Chem. 2005, 44, 7970.

2. Labuda, J.; Bubnicova, K.; Bubnicova, L.; Vanickova, M.; Vanickova, J.; Wennrich, R.; Sensors 2005, 5, 411.

3. Carter, T. M.; Rodriguez, M.; Bard, A. J.; J. Am. Chem. Soc. 1989, 111, 8901.

4. Carter, T. M.; Bard, A. J.; Bioconjugate Chem. 1990, 1, 257.

5. Cao, J.; Jia, L.; Zhou, H-M.; Lui, Y.; Zhong, L-F.; Toxicol. Sci. 2006, 91, 476.

6. Lin, P-H.; Nakamura, J.; Yamaguchi, S.; Upton, P. B.; La, D. K.; Swenberg, J. A.; Carcinogenesis 2001, 22, 627.
7. Oliveira-Brett, A. M.; Paquim, A.; Diculescu, V.; Piedade, J.; Medical Eng. Physics 2006, 28, 963.

8. Radi, A.; El Ries, M. A.; Kandil, S.; Anal. Chim. Acta. 2003, 495, 61.

9. Abd El-Hady, D.; Abdel-Hamid, M. I.; Seliem, M.M.; El-Maali, N. A.; Talanta 2005, 66, 1207.

10. Wang, L.; Lin, L.; Ye, B.; J. Pharmac. Biomed. Anal. 2006, 42, 625.

11. Ibrahim, M. S.; Shehatta, I. S.; Al-Nayeli, A. A.; J. Pharm. Biomed. Anal. 2002, 28, 217.

12. Girousi, S. T.; Gheghi, I. C.; Karava, M. K.; J. Pharm. Biomed. Anal. 2004, 36, 851 .

13. Piedade, J. A. P.; Fernandes, I. R.; Brett, A. M. O.; Bioelectrochem. 2002, 56, 81 .

14. Tagbor, H.; Bruce, J.; Browne, E.; Randal, A.; Greenwood, B.; Chandramohan, D.; The Lancet 2006, 368, 1349.

15. Obonyo, C. O.; Juma, E. A.; Ogutu, B. R.; Vulule, J. M.; Lau, J.; Trans. Royal Soc. Trop. Med. Hyg. 2007, 101, 117.

16. Binder, R.; Bornmann, S.; Adegnika, A.; Missinou, M.; Kremsner, P.; Kun, J.; Parasitol. Res. 2002, 88, 475.

17. Chen, N.; Wilson, D. W.; Pasay, C.; Bell, D.; Martin, L.; Kyle, D.; Cheng, Q.; Antimicrob. Agents. Chemother. 2005, 49, 2102.

18. Radi, A.; Talanta 2005, 65, 271.

19. Koram, K. A.; Abuaku, B.; Duah, N.; Quashie, N.; Acta Tropica 2005, 95, 194.

20. Kofoed, P-E.; Ursing, J.; Poulsen, A.; Rodrigues, A.; Bergquist, Y.; Aaby, P.; Rombo, L.; Trans. Royal Soc. Trop. Med. Hyg. 2007, 101, 231.

21. Britton, H. T. S.; Hydrogen Ions, $4^{\text {th }}$ ed.; Chapman Hall: London, 1952 , p. 110.

22. Brett, C. M. A.; Brett, A. M. O.; Serrano, S. H. P.; J. Electroanal. Chem. 1994, 366, 225

23. Frisch, M. J.; Trucks, G. W.; Schlegel, H. B.; Scuseria, G. E.; Robb, M. A.; Cheeseman, J. R.; Montgomery, Jr., J. A.; Vreven, T.; Kudin, K. N.; Burant, J. C.; Millam, J. M.; Iyengar, S. S.; Tomasi, J.; Barone, V.; Mennucci, B.; Cossi, M.; Scalmani, G.; Rega, N.; Petersson, G. A.; Nakatsuji, H.; Hada, M.; Ehara, M.; Toyota, K.; Fukuda, R.; Hasegawa, J.; Ishida, M.; Nakajima, T.; Honda, Y.; Kitao, O.; Nakai, H.; Klene, M.; Li, X.; Knox, J. E.; Hratchian, H. P.; Cross, J. B.; Bakken, V.; Adamo, C.; Jaramillo, J.; Gomperts, R.; Stratmann, R. E.; Yazyev, O.; Austin, A. J.; Cammi, R.; Pomelli, C.; Ochterski, J. W.; Ayala, P. Y.; Morokuma, K.; Voth, G. A.; Salvador, P.; Dannenberg, J. J.; Zakrzewski, V. G.; Dapprich, S.; Daniels, A. D.; Strain, M. C.; Farkas, O.; Malick, D. K.; Rabuck, A. D.; Raghavachari, K.; Foresman, J. B.; Ortiz, J. V.; Cui, Q.; Baboul, A. G.; Clifford, S.; Cioslowski, J.; Stefanov, B. B.; Liu, G.; Liashenko, A.; Piskorz, P.; Komaromi, I.; Martin, R. L.; Fox, D. J.; Keith, T.; Al-Laham, M. A.; Peng, C. Y.; Nanayakkara, A.; Challacombe, M.; Gill, P. M. W.; Johnson, B.; Chen, W.; Wong, M. W.; Gonzalez, C.; And Pople, J. A.; Gaussian 03, Revision D. 02, Gaussian, Wallingford CT, 2004.

24. Becke, A. D.; J. Chem. Phys. 1993, 98, 5648; Lee, C.; Yang, W.; Parr, R. G.; Phys. Rev. B 1988, 37, 785.

25. Gaussview 3.0; Gaussian, Inc., Cornegie Office Park-Building 6 Pittsburg Pa 15106 USA.

26. Zuman, P.; The Elucidation of Organic Electrode Processes, Academic Press. Inc.: New York, 1969, p. 21.

27. Kirkbright, G. F.; Stock, J. T., Pugliese, R. D.; Bobbitt, J. M.; J. Electrochem. Soc. 1969, 116, 219.

28. Hammerich, O. In Anodic Oxidation of Oxygen-Containing Compounds; Baizer, M. M.; Lund, H.; eds; Marcel Dekker Inc.: New York, 1989, p. 485 .

29. Edwards, D. I. In Comprehensive Medicinal Chemistry; Hansch, C.; Sammes, P. G., eds.; Pergamon Press: Oxford, 1990, vol. 2.

30. Paula, F. R.; Serrano, S. H. P.; Tavares, L. C.; Quim. Nova 2009, 32, 1013.

31. Pang, D. W.; Abruña, H. D.; Anal. Chem. 1998, 70, 3162. 
32. Pang, D-W.; Abruña, H. D.; Anal. Chem. 2000, 72, 4700.

33. Brett, A. M. O.; Serrano, S. H. P., Piedade, J. A. P. In Electrochemistry of DNA; Compton, R. G.; G. Hancock, G., eds.; Elsevier: Amsterdam, 1999, vol. 37, cap. 3.

34. Shapiro, R.; Ellis, S.; Hingerty, B. E.; Broyde, S.; Chem. Res. Toxicol. 1998, 11, 335.

35. Fan, S.; Ohms, S. J.; Boyd, M.; Denny, W. A.; Chem. Res. Toxicol. 1999, $12,1166$.

36. Galiegue-Zouitina, S.; Baileul, B.; Loucheux-Lefebvre, M-H.; Cancer Res. 1985, 45, 520.

37. Soglia, J. R.; Turesky, R. J.; Paehler, A.; Vouros, P.; Anal. Chem. 2001, $73,2819$.

38. Li, K-M.; Todorovic, R.; Devanesan, P.; Higginbotham, S.; Koefeler, H.; Ramanathan, R.; Carcinogenesis 2004, 25, 289.
39. Cavalieri, E. L.; Rogan, E. G.; Chakravarti, D.; Cell Mol. Life Sci. 2002, $59,665$.

40. Saeed, M.; Gunselman, J. S.; Higginboth, S.; Rogan, E.; Cavalieri, E.; Steroids 2005, 75, 37.

41. Domingo, L. R.; Aurell, M. P.; Pérez, P.; Contreras, R. J.; J. Org. Chem. 2003, 68, 3884

42. Parr, R. G.; Von Szentpaly, L.; Liu, S.; J. Am. Chem. Soc. 1999, 121, 1922.

43. Parr, R. G.; Yang, W.; Density Functional Theory of Atoms and Molecules, Oxford University Press: New York, 1989; Parr, R. G.; Pearson, R. G.; J. Am. Chem. Soc. 1983, 105, 7512. 


\section{ELECTROCHEMICAL AND THEORETICAL EVALUATION OF THE INTERACTION BETWEEN DNA AND} AMODIAQUINE. EVIDENCE OF THE GUANINE ADDUCT FORMATION

Maria Lara P. M. Arguelho* e José do Patrocínio H. Alves

Departamento de Química, Universidade Federal de Sergipe, 49100-000 São Cristovão - SE, Brasil

Nelson R. Stradiotto

Instituto de Química, Universidade Estadual Paulista, CP 355,14801-970 Araraquara - SP, Brasil

Valdemar Lacerda Júnior e José Maria Pires

Departamento de Química, Universidade Federal do Espírito Santo, 29075-910 Vitória - ES, Brasil

Adilson Beatriz

Departamento de Química, Universidade Federal de Mato Grosso do Sul, 79070-900 Campo Grande - MS, Brasil

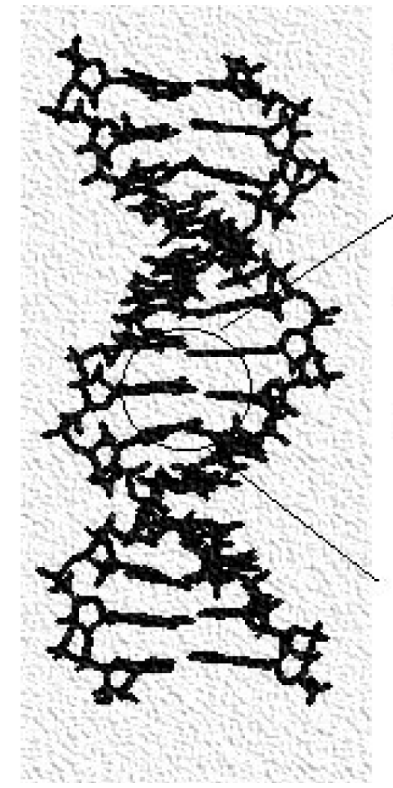

guanine oxidation<smiles>Nc1nc2[nH]c([18OH])nc2c(=O)[nH]1</smiles><smiles>Nc1nc2[nH]c(=O)[nH]c2c(=O)[nH]1</smiles>

adenine oxidation<smiles>Nc1nc(=O)[nH]c2c1ncn2[18OH]</smiles>

Scheme 1S. Oxidation mechanism of guanine and adenine

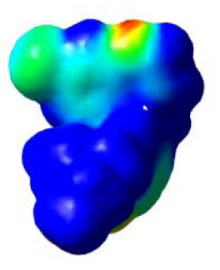<smiles>CCN(CC)Cc1cc(Nc2ccnc3cc(Cl)ccc23)ccc1O</smiles>

AMD

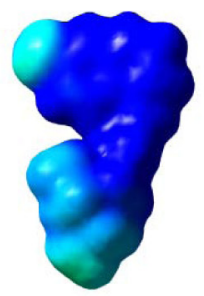<smiles>CCN(C)Cc1cc(Nc2cc[nH+]c3cc(Cl)ccc23)ccc1O</smiles>

AMD-H
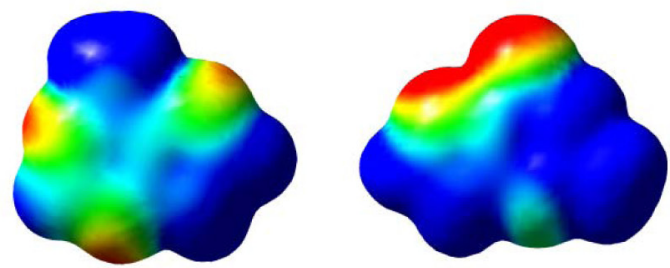<smiles>Nc1ncnc2[nH]cnc12</smiles>

ADE<smiles>[3H]Nc1nc2[nH]cnc2c(=O)[nH]1</smiles>

GUA

Figure 1S. Space-filling models and MEP of the compounds studied. Electrostatic potentials are mapped on the surfaces. Red denotes negative potential and blue positive potential 